International Journal of Business and Management 4 (3): 22-39, 2020

e-ISSN: 2590-3721

(C) RMP Publications, 2020

DOI: $10.26666 /$ rmp.ijbm.2020.3.4

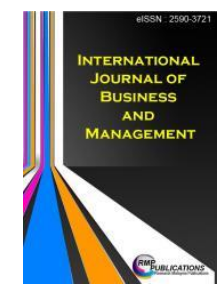

\title{
INVESTIGATING KNOWLEDGE CREATION PROCESSES AMONG THE ROYAL MALAYSIAN NAVY (RMN) FLEET PERSONNEL
}

\author{
Shaftdean Lufty Rusland, Noor Ismawati Jaafar \\ Department of Operation and Management Information System, Faculty of Business and Accountancy, \\ University of Malaya, Malaysia
}

\begin{abstract}
This study was conducted to gauge the extent of knowledge creation within the Royal Malaysian Navy (RMN) fleet. It was due to rotational of personnel serving on board for their career progressions and personnel retired that may bring with them substantial amount of knowledge. Thus, quantitative study was conducted, taking into account of descriptive data analyzed by SPSS software with 234 respondents utilizing SECI model as the theoretical platform. Items analysis was conducted to gauge the extent. Apart from that, level and type of knowledge, mechanisms and venues for knowledge creation were identified. The results showed the extent of knowledge creation processes varied in every mode of SECI. Operational knowledge and knowledge from experiences are common within the fleet. Social media identified as the common mechanism utilized. Seminar, workshop and meeting were identified as the venues for most of the knowledge creation processes took place. Besides identifying the extent of knowledge creation processes, this study could be the platform for the fleet to identify suitable recommendation to create and capture more knowledge, to retain and to disseminate knowledge in order to improve fleet operations.
\end{abstract}

Keywords: Knowledge Creation, Knowledge Management, Tacit Knowledge, Explicit Knowledge, SECI Model

\section{INTRODUCTION}

The survivability and development of organizations depend on knowledge since knowledge is part of the competency necessary for personnel in performing effectively [1] [2]. Shih, Chang and Lin [3] posited that the main input for organizations is knowledge and personnel within the organizations. Human knowledge is so important that it involves the current dynamic and rapid change of complex knowledge which is crucial to the organizations. Previous researchers [4] [5] [6], on the other hand, claimed that organization is a body of knowledge. They added that if the knowledge is properly leveraged within the organization, its importance can far exceed the physical resources. The initiatives of knowledge management (KM) are principally depending on how personnel share knowledge among them [7] [8]. Hence, in managing knowledge, organization emphasizes on knowledge creation and knowledge sharing, which are part of the KM processes [9].
Most successful organizations constantly create new knowledge [10]. Knowledge creation is the first stage in the life cycle of knowledge [11] [12]. Knowledge creation is seen to be the initiating component in KM and it is so critical that most of the organizations are trying their best to be competitive by creating knowledge that will assist them to achieve their objectives [13]. On top of that, military organizations all around the world agree that the personnel within their organizations are actually their main and most vital assets and at the same time the sources of their organizational knowledge [14]. So, when personnel are transferred or retired from the organization, they leave with lots of knowledge that they have accumulated over their working years. This knowledge base must then to be re-created, re-built or reconstructed by new personnel who take up the posts. Thus, Nielsen and Razmerita [15] emphasized the need for managers and management to get actively involved in motivating and encouraging knowledge creation and knowledge sharing among personnel.

Corresponding Author: Noor Ismawati Jaafar, Department of Operation and Management Information System, Faculty of Business \& Accountancy, University of Malaya, 50630 Kuala Lumpur, Malaysia. E-mail: isma_jaafar@um.edu.my 
In the RMN fleet, saving created knowledge from dissipating due to personnel transfer or retirement is crucial in order to remain relevant in safeguarding the nation's maritime sovereignty. The fleet safe operations might be jeopardized without this valuable knowledge. This can be witnessed in the few mishaps which happened within the fleet, even though they were isolated cases [16] [17]. Unwanted incidences, for instance, collision at sea or fire on board, were associated with lack of competencies. Competencies can be defined as the combination of skills, knowledge, attitudes and behaviours of personnel required for performing effectively [2]. Both mishaps are avoidable if every personnel serving on board a vessel has adequate knowledge i.e. competent to respond to the situation. Liu et al. [18] further described that competency is the knowledge owned by the personnel or their skills demonstrated by behaviours at the workplace.

The transformation plan for the RMN will witness more newly built vessels to come into the RMN inventory with state-of-the-art capabilities and estimated to be worth of billions Malaysian Ringgit. Without proper management of the knowledge gained from the Original Equipment Manufacturer (OEM) on how to operate and to maintain those vessels, dissipation or loss of knowledge will occur. Again to ensure that the RMN does not lose the knowledge, all the four main practices of KM inclusive of knowledge creation need to be inculcated immediately [19].

Therefore, this study is to disclose whether knowledge creation is an important phenomenon within the RMN fleet by determining the current extent of the process for fleet operation improvement. This study is also stressing on the importance of knowledge, not only capitalizing on the development of resources but also to encourage and motivate knowledge creation and sharing [20], to build the fleet readiness as a knowledge-based organization and maintaining the safety aspects throughout the RMN fleet operations.

The focus on knowledge processes in this study is based on the SECI Model proposed by Nonaka and Takeuchi [21]. SECI Model in the study of management and organization, has provided the platform and framework which vastly covers knowledge sharing and knowledge creation process [22] [23]. Hence, a quantitative method utilizing this model was employed to investigate the issues related to the RMN fleet through a survey among relevant personnel.

\section{LITERATURE REVIEW}

In the military context, the inadequacy of $\mathrm{KM}$ was mainly due to low awareness and also lack of understanding [14]. Bartczak [24] found that managerial, resources and environmental influence as the challenges in implementing KM within the United States (US) military, apart from funding, confusion, commitment and leadership education. Ali and Ahmad [25] posited that the implementation of KM in the military context is still a dilemma. According to them, the intricacy of the military environment makes it impracticable to exercise $\mathrm{KM}$ in military operation especially with regards to dealing with lots of data and information. The vast flow of data and information that will be arriving simultaneously in military operation are difficult to manage, able to create confusion and may lead to misinterpreting or misconception of the information if the user is not careful. Nevertheless, most of the world class military are adopting $\mathrm{KM}$ in order to achieve sustainable competitive advantages [26]. Ali and Ahmad [25] further posited that $\mathrm{KM}$ is intended to inspire and support new knowledge creation as crucial element in military operations success.

\section{Knowledge}

Knowledge is deemed as the main organizational asset that is able to produce competitive advantage if it is exploited correctly [4] [6] [27]. According to Dalkir [28], there are many overlapping categories of types of knowledge. Nonaka and Takeuchi [21] came up with the 'Justified True Belief' concept of knowledge which stated that given a true proposition, one must not only believe but must have to listen to the justification behind it. Gunnlaugsdottir [29] in his study mentioned about the utilization of knowledge as the prime mover of organization's competitive advantage and also for the global economy. According to Mahdi, Nassar and Almsafir [30] knowledge has been considered as a strategic resource and as such, it needs to be managed to promote the competitive performance of the organization.

Knowledge can also be defined as the link between information; in particular, when information is put into logic and being understood, where one can verify or recall from their own experiences [29]. However, Davenport and Marchand [31] argued that this 
knowledge will remain as information until it remains in personnel's mind and when personnel can deduce meaning from the information with their cognitive capacity and has ability to interpret, it will lead to knowledge creation [32] [33].

\section{Types of Knowledge}

Knowledge is considered to be a high-value form of information because of its added experience, context, interpretation and reflection [34]. There are few types of knowledge and the common ones are tacit and explicit. [35] was among the first researcher to classify tacit and explicit knowledge. Sikombe and Phiri [4]; Chugh [36] differentiate the knowledge into two, which are tacit and explicit knowledge that are intangible and tangible from the KM perspective. They added that it is vital to identify this knowledge so that organization can exploit it for organizational success.

Tacit knowledge is the knowledge that people have in their minds, whereas explicit knowledge is the kind of knowledge that is captured or written down [37]. The main difference between the two is that tacit knowledge cannot be accessed as easily as explicit knowledge. Tacit knowledge is less vulnerable but less accessible to personnel and explicit knowledge is more accessible but more vulnerable to illegitimate exploitation [38].

\section{Tacit Knowledge}

Tacit knowledge is the personal and intangible knowledge that is very hard to enunciate with the use of formal language [39]. Wilson [40] added that tacit knowledge is the personal knowledge that is impossible to be communicated in formal and also systematic languages. Nonaka and Takeuchi [32] posited the awareness and importance of tacit knowledge has been generally accepted in the literature of KM as a powerful element. Collins [41] posited that tacit knowledge is highly personal, context specific and deeply rooted in an individual's emotions, values, ideas and experiences and there is no doubt that in the sophisticated RMN fleet, there are lots of tacit knowledge that require to be transferred despite all the available documentations.

However, tacit knowledge cannot be easily transferred by only using word or writing, but may be done by the mean of mentoring and shadowing processes [42]. Since this knowledge is contained within personnel's minds and due to the individual's epistemology possession, it is very difficult to access and cannot be detached easily [33]. Sikombe and Phiri [4] added that it is because of tacit knowledge nature influenced by social embeddedness that is characterized by trust, culture and also close relationship between personnel.

\section{Explicit Knowledge}

Wilson [40] posited that explicit knowledge is the knowledge that can be communicated in formal and systematic languages. Explicit knowledge is more expressive, objective and rational and this knowledge can be easily distributed or transmitted [43].

Few researchers such as Shih, Chang and Lin [3]; Nonaka and Takeuchi [44]; Suppiah and Sandhu [43] posited that explicit knowledge is easy to codify and write down or being documented to be transmitted either manually or electronically and Rutten, BlaasFranken and Martin [42] added that explicit knowledge is the knowledge that can be easily transferred by using word or writing. Meanwhile, Meanwhile, Park, Vertinsky and Becerra [45] posited that explicit knowledge is the knowledge that has been articulated, codified, and stored. In the RMN fleet context, all this knowledge can be learned from written materials and readily available for others, such as doctrines, SOPs, manuals, standing orders, minutes etc.

\section{Knowledge Creation}

Mehralian, Nazari and Ghasemzadeh [13] opined that in whatever ways $\mathrm{KM}$ is defined in previous studies, knowledge creation process is seen to be the most vital and important in KM activities. Creation of knowledge process is a process of learning [46] as argued by Garvin [47] that by learning from experience, solving problems, experimenting with new approaches and sharing knowledge, new knowledge created.

Jogulu and Pansiri [48] quoted that knowledge creation refers to different findings created through multiple data collection and analysis techniques provide insightfulness and extensiveness in overall results, from which the researchers can make more accurate inferences with increased credibility. On the other hand, Memon [1] posited that the researchers cannot abolish the influence of people, place and structure of the knowledge creation process during empirical investigation. He further added that influence of the higher echelon during knowledge 
creation process, might also give impact to the process with regards to policies and decisions. Hence, making it very interesting to investigate further the knowledge creation extent in the RMN fleet.

\section{SECI Model}

Nonaka and Takeuchi [21] came out with one of the most influential theory of knowledge creation, which argued that interaction between tacit and explicit knowledge via socialization, externalization, combination and internalization, leads to new knowledge creation [46] [21] [49]. According to Schaap et al., [51]; Baldé, Ferreira and Maynard [52], study on personnel involve in SECI model is scarce and [52] posited that the picture is still incomplete even though numerous researches have been conducted on SECI Model. A study by Yeh, Huang and Yeh [53] established that respondents' (in educational science) professional knowledge increased after working through the model. However, it was unclear on how and in what order they actually engaged in SECI. Hubers et al., [54] posited that it is still yet unknown, whether personnel are engaged in SECI in similar or different manner. They further theorized that the way personnel engages in SECI influences knowledge creation processes.

In KM studies, the SECI Model (Figure 1) has been widely used. It is universal and can also be generalize in other sectors for instance, educational science, resource-based industry, product systems development and also financial [55] and entrepreneurship [56]. The researchers feel that it can be generalize in the military context too.

This study attempted to provide clearer understanding in the aspects of each process contains in the SECI Model among the personnel in the RMN fleet. The personnel were divided into senior, middle and lower management level to get comprehensive insights at all level of management. Huang, Basu and Hsu [57] stated that the application of SECI Model enriched the insights of the organization into their knowledge creation and processes involved.

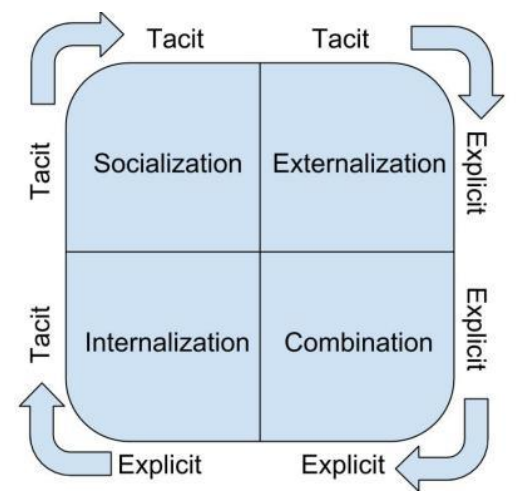

Sources: Nonaka and Takeuchi (1995)

Figure 1 : SECI Model - Knowledge Creation
Process

Socialization mode of SECI Model is about sharing experiences through social interaction where the element of tacit knowledge being shared and created [44]. Externalization and internalization modes associated with tacit and explicit knowledge conversion, as both tacit and explicit knowledge are complementing each other [10]. Memon [1] posited that in externalization mode, the conversion of tacit knowledge which is subjective, intangible and inexpressible to explicit knowledge which is objective, tangible and expressible is taking place. Mehralian, Nazari and Ghasemzadeh [13] added that tacit knowledge is "articulated and crystallized" into explicit knowledge and shared among personnel to become the basis or foundation of new knowledge.

Meanwhile, in internalization mode, Nonaka, Toyama and Konno [49] posited that it is the process where knowledge becoming valuable when it is internalized in personnel. This process is actually closely related to learning-by-doing process [44]. In other words, internalization is the process where organizational knowledge is converted back into individual personnel knowledge [58]. Mehralian, Nazari and Ghasemzadeh [13] opined that it can be mentioned as the experiential learning process, where explicit knowledge becomes part of personnel's knowledge and eventually becomes the important organizational asset.

Combination mode explains about creating explicit from explicit knowledge and knowledge conversion involves social processes to combine different bodies of explicit knowledge held by individuals [10]. In the combination mode, creation of knowledge process includes existing explicit knowledge converted into 
more systematic sets of explicit knowledge [59] that can be disseminate throughout the organization [13].

Hence, to this extent, we know that every mode in SECI model can create knowledge independently. However, the most important thing here is the dynamic interaction between all modes of knowledge creation that are going to be investigated in this study within the RMN fleet.

\section{RESEARCH METHODOLOGY}

This study embarked on quantitative method using the SECI Model proposed by [21]. The study was conducted in the maritime scenario i.e. on board selected ships from the fleet and excluded other units in the RMN because the fleet forms the backbone of the RMN. 300 respondents were selected to answer the survey questionnaire and they were based on the justification of their roles as the senior, middle and lower management levels in relation to knowledge creation processes based on the SECI Model.

\section{Research Ethic}

The participation for the survey was on voluntary basis and the fleet personnel were answering the questions on behalf of themselves. Information was given to the respondents with regards to this by the means of consent form and they were free to withdraw at any time if they were uncomfortable and felt like doing so. Apart from that, prior to conducting the data collection, authorization was obtained from the University Malaya Research Ethic Committee (UMREC). This was in order for the researchers to assure the respondents with regard to compliance with certain ethical standards set by the university deemed to be mandatory in the data collection process. Hence, the respondents were guaranteed anonymity and confidentiality with their responses and personal details.

\section{Questionnaire Design}

The study was conducted with the use of a five-point Likert scale questionnaire adapted from [59] to determine the extent of knowledge creation processes within the RMN fleet. Apart from that, the questionnaire was also to determine the level of knowledge, type of knowledge, mechanisms for knowledge creation and most common venues for knowledge creation within the fleet.

\section{Research Framework}

In order to answer the questions and to achieve the objectives of this study, a research framework as shown in Figure 2 was utilized. This framework is the SECI Model and in this study, the researchers looked into the knowledge creation processes namely the socialization, externalization, combination and internalization perspectives.

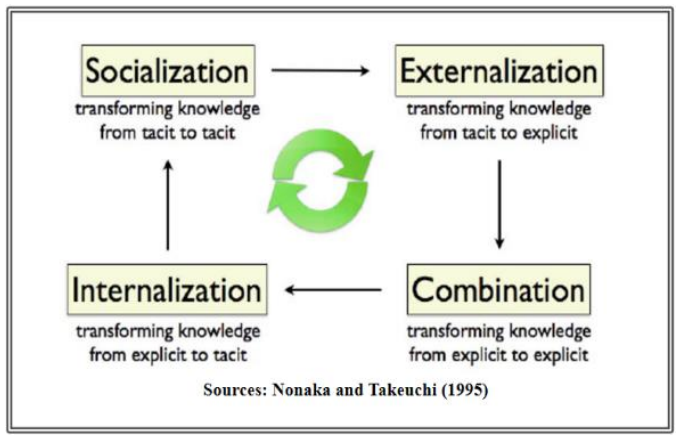

Figure 2 : Research Framework - Knowledge Creation Process

\section{Data Collection}

Data were collected using set of questionnaires adapted from [59]. McClure and Faraj [60] mentioned that it is necessary to use questionnaires since it seems to be almost impossible to interview every single personnel in an organization to obtain relevant data and information. So, a survey using questionnaire was conducted to get the gist of the research.

The researchers used stratified random sampling to highlight a specific subgroup within the population. It is the most efficient technique where all groups are adequately sampled and comparisons among them are possible [61]. Proportionate allocation was used in this study to infer the results that represent the whole RMN fleet. Hence, the fleet personnel were stratified into senior, middle and lower management level. The senior level of management comprised officers with the rank of Lieutenant Commander and above. The middle level was from Petty Officer to Lieutenant, and the lower level was Leading Rate and below.

There were approximately 400 personnel serving on board the warships selected and according to Sekaran [62], 200 respondents are adequate for this study. However, the researchers took 300 respondents and a collective administrative survey was conducted, as the nature of the personnel on board allowed the researcher to carry out such a survey, to ensure a high 
response rate and to have personal contact with the participants [63]. Only 234 (78\%) questionnaires were analysed because 66 (22\%) questionnaires were either incomplete or had multiple answers for one question and were thus rejected and removed from the data set. Prior to the selection of samples, the researchers identified different types of ship from different squadrons for sampling. They were a frigate, a corvette, a new generation patrol vessel (NGPV) and a multi-purpose command support ship (MPCSS) that were located at the Lumut Naval Base. These ships were selected based on their importance in fleet operations, narrowed down to squadron leaders or the representative of the type of ships which adequately represented the fleet as a whole.

\section{DATA ANALYSIS}

Table 1 : Demographic Data of RMN Fleet Personnel $(\mathrm{N}=234)$

\begin{tabular}{|c|c|c|c|}
\hline Demographic & & Frequency & $\begin{array}{c}\text { Percentage } \\
(\%)\end{array}$ \\
\hline \multirow[t]{2}{*}{ Gender } & Male & 223 & 95.3 \\
\hline & Female & 11 & 4.7 \\
\hline \multirow{4}{*}{$\begin{array}{l}\text { Highest } \\
\text { Education }\end{array}$} & High achool & 159 & 67.9 \\
\hline & Diploma & 49 & 20.9 \\
\hline & lst degree & 21 & 9.0 \\
\hline & Master's degree & 5 & 2.1 \\
\hline \multirow[t]{3}{*}{ Job Position } & Lower & 119 & 50.9 \\
\hline & Middle & 62 & 26.5 \\
\hline & Senior & 53 & 22.6 \\
\hline \multirow{4}{*}{$\begin{array}{l}\text { Length of } \\
\text { service in } \\
\text { current post }\end{array}$} & Under 1 year & 35 & 15.0 \\
\hline & $1-2$ years & 42 & 17.9 \\
\hline & $2-3$ years & 34 & 14.5 \\
\hline & More than 3 years & 123 & 52.6 \\
\hline \multirow[t]{3}{*}{ Ship's type } & Frigate/Corvette & 92 & 36.3 \\
\hline & $\begin{array}{l}\text { New Generstion } \\
\text { Patrol Vessel } \\
\text { (NGPV) }\end{array}$ & 63 & 26.9 \\
\hline & $\begin{array}{l}\text { Multi-Purpoge } \\
\text { Command } \\
\text { Support Ship } \\
\text { (MPCSS) }\end{array}$ & 79 & 33.8 \\
\hline \multirow[t]{4}{*}{ Department } & Operstions & 84 & 35.9 \\
\hline & Technical & 81 & 34.6 \\
\hline & Logistics & 37 & 15.8 \\
\hline & Others & 32 & 13.7 \\
\hline \multirow{4}{*}{$\begin{array}{l}\text { Number of } \\
\text { times in } \\
\text { training since } \\
\text { appointed on } \\
\text { board }\end{array}$} & Never & 16 & 6.8 \\
\hline & Once & 47 & 20.1 \\
\hline & Twice & 62 & 26.5 \\
\hline & $\begin{array}{l}\text { More than two } \\
\text { times }\end{array}$ & 109 & 46.6 \\
\hline
\end{tabular}

The SPSS version 24 software was used to analyze the data collected from the survey. Data analysis uses a frequency distribution to explore the agreement of respondents regarding the performance of SECI knowledge creation process model. Statistical analysis of the data from the questionnaire responses were used to answer the questions and accomplish the objectives that suited the context of this research which is to explain in more detail the extent of knowledge creation processes in the RMN fleet based on the SECI model.The sample distribution according to the types of ships and the demographic characteristics such as gender, academic background, job position, length of service, departments and number of training as per listed in Table 1.

Validity and reliability tests were conducted after data entry to ensure the quality of the questionnaire. Sekaran [61] posited that validity is how accurate instrument measuring the measure. The validity of the instrument could also be established by using instrument that already validated in other studies or by other researchers [64]. Therefore, the instrument used was adapted from [59], only in a different context, i.e. the RMN fleet context. On the other hand, Treiman [65] opined that reliability test is to measures instrument that can produce consistent results.Cronbach Alpha was utilized and the score for every instrument items with regards to the individual SECI mode was more than $80 \%$ (see Table 2). The instrument was tested reliable and valid in the RMN fleet context.

Table 2: Reliability Test Result

\begin{tabular}{|l|c|}
\hline SECI Mode (items) & Cronbach Alpha ( $\boldsymbol{\alpha}$ ) \\
\hline Socialization (14) & .835 \\
Externalization (13) & .856 \\
Combination (13) & .846 \\
Internalization (13) & .863 \\
\hline
\end{tabular}

Next, the researchers identified the mechanisms required to create and capture knowledge within the fleet. Additional results like the venues where knowledge creation took place in the RMN fleet, level of knowledge and type of knowledge possessed by the RMN fleet's personnel are very helpful in achieving the objectives of this study. The final part of descriptive analysis focuses on testing the difference between the respondents' demographic information regarding SECI knowledge creation process activities using One-way ANOVA. 


\section{Mechanisms Used in Knowledge Creation}

Figure 3 shows the most popular mechanisms according to the percentage used. Social multimedia seems to have lots of effect in the knowledge creation process within the fleet. It is clearly showed that all levels were using the multimedia means to share and create knowledge among them. The most popular tools according to frequency of used and trend were whatsapp, facebook, email and youtube. Whatsapp was the most utilized mechanism with $88.0 \%$ respondents had used it. The second tool was Facebook with 52.6\%. Email and YouTube were utilized by the respondents, $47.9 \%$ and $46.6 \%$ respectively. However, face-to-face session cannot be disregard since it plays major part of the SECI Model knowledge creation process as per mentioned by [21] and $38.9 \%$ respondents feel that it was part of mechanisms for knowledge creation process.

This indicates that there are available mechanisms being used by the RMN fleet personnel to exchange information, for sharing ideas, opinions etc. However, the extent of utilization varies and the extent of knowledge creation in the fleet still remain in the dark while utilizing these available mechanisms.

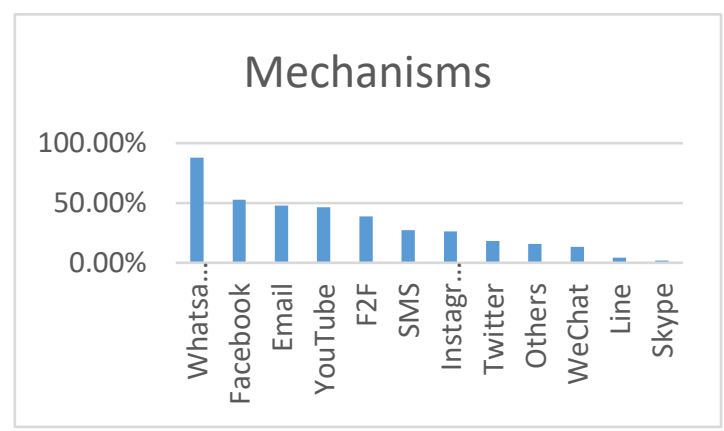

Figure 3: Mechanisms Used in Knowledge Creation

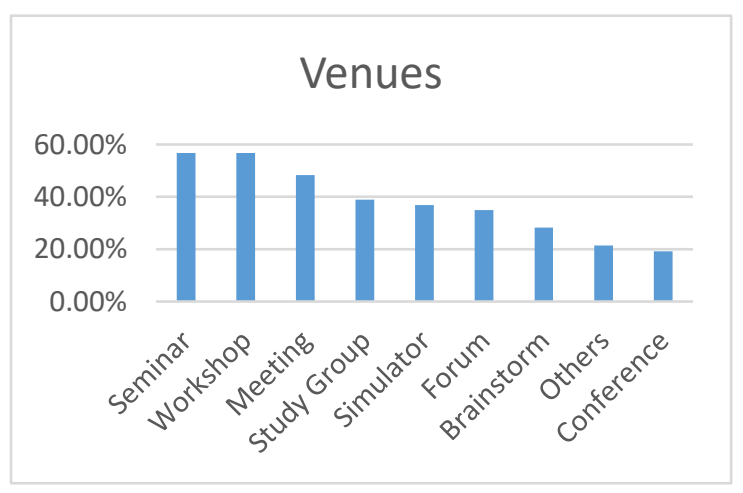

Figure 4 : Venues for Knowledge Creation

\section{Venues for Knowledge Creation}

In Figure 4, it is shown that respondents chose seminar and workshop as the most popular venues to create knowledge, both representing 56.8\%. Meeting, study group and simulator were $48.3 \%, 38.9 \%$ and $36.8 \%$ respectively. This shows that in the RMN fleet, there were venues where knowledge creation took place but how effective and efficient these venues can become the platform of knowledge creation, will largely depend on the performance of the fleet itself.

\section{Analysis of Variance}

Further analysis utilizing demographic information of the respondents with the modes in the knowledge creation process based on SECI Model were carried out. One-way Analysis of Variance (ANOVA) was conducted and the results as per Table 2 .

Table 2: One-way ANOVA for Demographic Details and SECI Modes

\begin{tabular}{|c|c|c|c|c|c|c|c|c|c|c|c|c|}
\hline \multicolumn{13}{|c|}{ One-ाтау ANOVA } \\
\hline & \multicolumn{2}{|c|}{ Academic } & \multicolumn{2}{|c|}{ Position } & \multicolumn{2}{|c|}{ LengthSTc } & \multicolumn{2}{|c|}{ Ship } & \multicolumn{2}{|c|}{ Department } & \multicolumn{2}{|c|}{ Training } \\
\hline & $\mathrm{F}$ & Sig. & $\mathrm{F}$ & Sig. & $\mathrm{F}$ & Sig & $\mathrm{F}$ & Sig, & $F$ & Sig. & $\mathrm{F}$ & Sig. \\
\hline Socialization & 1.814 & .145 & .722 & .487 & 1.971 & .119 & 3.871 & $.022^{* *}$ & .641 & .590 & 4.667 & $.003^{* * * 4}$ \\
\hline Extemalization & 1.945 & .123 & 1.583 & .2082 & 2.183 & .091 & 4.996 & $.0094 *$ & .516 & .672 & 2.633 & $.050^{* *}$ \\
\hline Combination & 1.652 & .178 & .662 & 517 & \begin{tabular}{|l|l|} 
\\
\end{tabular} & 335 & 2.231 & $.010^{* 4 *}$ & .268 & .849 & 2.671 & $.048^{4 *}$ \\
\hline Intemalization & 3.705 & $.012^{2 *}$ & .707 & 4942 & 2.262 & .082 & 4.204 & $.016^{* *}$ & 612 & .608 & 3.055 & $.029^{* *}$ \\
\hline
\end{tabular}

Based on the results, the researcher can derive that type of ships and training frequencies were having significant values with all four processes of knowledge creation that was based on the model. The values for socialization phase with ship and training are .022 and .003 which are significant, since they are less than .05 $(* *)$ and $.01(* * *)$ respectively. For externalization, the values are .009 and .05 , for combination, the values are .01 and .048 and lastly, for internalization, the values are .016 and .029 and they are all significant values.

In the RMN fleet there are few types of ship in her inventory that are grouped into squadrons. These squadrons are determined by the ship's capabilities. 
For instance, a frigate is an example of combatant vessel where they are equipped with state-of-the-art technology of systems, sensors and weaponry to fight in the Anti Surface Warfare, Anti Submarine Warfare, Anti Air Warfare, Electronic Warfare etc. Meanwhile, there are some vessels which are categorized in the supporting or logistic roles such as Multi Purpose Command Support Ship (MPCSS).

The researchers can derive from the analysis that the types of ship will determine the number of training, exercises or even operations involved. With that kind of exposures, the crew need to attend lots of knowledge creation activities from courses, classes, seminars, workshops etc., to become specialized.

Furthermore, ships that are fitted with advanced technology need competent crew to operates them. Hence, the difference between personnel on board high technologically equipped warship with the one which is not so, is quite significant. So, in the case of the RMN fleet, the knowledge creation process will take place more on board a frigate compared to MPCSS and that was why from the one-way ANOVA analysis, the study gave values which are significant to the types of ship with the SECI Model. Therefore, it indicates that the activities involved in the model are taking place on board.

Secondly, as mentioned for the types of ship, combatant vessel needs more training compared to the rest of the vessel in the RMN fleet inventory. The crew has to be competent in handling state-of-the-art and technologically advanced equipment. The training must also include the application of knowledge in warfare scenarios; on how to fully utilize equipment fitted on board and to get the systems to work efficiently and effectively for the benefit of the organization.

\section{Level of Knowledge}

Table 3 : Fleet Personnel's Level of Knowledge

\begin{tabular}{|l|r|r|r|r|}
\hline $\begin{array}{l}\text { Level of } \\
\text { knowledge }\end{array}$ & Frequency & Percent & $\begin{array}{r}\text { Valid } \\
\text { percent }\end{array}$ & $\begin{array}{r}\text { Cumulative } \\
\text { Percent }\end{array}$ \\
\hline Conceptual & 48 & 20.5 & 20.5 & 20.5 \\
\hline Contextual & 41 & 17.5 & 17.5 & 38.0 \\
\hline Operational & $\mathbf{1 4 5}$ & $\mathbf{6 2 . 0}$ & 62.0 & 100.0 \\
\hline Total & 234 & 100.0 & 100.0 & \\
\hline
\end{tabular}

Meanwhile, for the level of knowledge, the most knowledge availability in the RMN fleet is operational knowledge. From Table 3, out of 234 respondents, 145 (62\%) claimed to possessed operational knowledge. This can be understood as the fleet is the operational wing of the RMN. The fleet is the backbone of the RMN and always carry the national flag in bilateral or multilateral operations, training and exercises, apart from safeguarding the sovereignty of nation's maritime interest.

\section{Types of Knowledge}

The most type of knowledge availability in the RMN fleet is from experiences. From Table 4, out of 234 respondents, $121(51.7 \%)$ claimed that they have experiences. Experiences are form of tacit knowledge that really important to the organization like the RMN fleet. The RMN personnel will undergo lots of training and courses pertaining to the ship's operation from day one that they started to join the RMN. The training can be divided into theoretical training which will be held normally in the training establishment and practical training either on board ship or training establishment. The journey that they had will allow them to accumulate experiences before serving on board. That was the main reason why most of the respondent in this study claimed that they have experience when asked about the type of knowledge that they possessed.

Table 4: Fleet Personnel's Type of Knowledge

\begin{tabular}{|l|r|r|r|r|}
\hline $\begin{array}{l}\text { Type of } \\
\text { knowledge }\end{array}$ & Frequency & Percent & $\begin{array}{r}\text { Valid } \\
\text { percent }\end{array}$ & $\begin{array}{r}\text { Cumulative } \\
\text { Percent }\end{array}$ \\
\hline Routine & 52 & 22.2 & 22.2 & 22.2 \\
\hline Experience & $\mathbf{1 2 1}$ & $\mathbf{5 1 . 7}$ & 51.7 & 73.9 \\
\hline Technical & 52 & 22.2 & 22.2 & 96.2 \\
\hline Others & 9 & 3.8 & 3.8 & 100.0 \\
\hline Total & 234 & 100.0 & 100.0 & \\
\hline
\end{tabular}

\section{Knowledge Creation Analysis}

The items analysis is divided into four modes:

\section{Socialization}

For socialization mode, the descriptive statistics (see table 5) show that the respondents acknowledged during discussions, they tried to find out others' opinions, concepts, thoughts or ideas when they socialized. The respondents often encouraged others to express their thoughts, concepts or ideas, and they agreed that they actively shared work or life experience with each other. Meanwhile, the highest mean value of 3.8675 for item S4, indicated that the 
respondents gathered information from other departments to equip themselves with knowledge.

The RMN fleet personnel collected necessary information and showed them to their colleagues before they engaged in any discussions. They also responded that they would like to get to know the people whom they would work with before working together, and the respondents then agreed that they collected work-related information and ideas in either formal or informal relationships with other people.

Table 5: Descriptive Statistics of Socialization Items (see Appendix 1)

\begin{tabular}{|l|l|l|l|}
\hline Item Code & $\mathbf{N}$ & Mean & Std. Deviation \\
\hline S13 & 234 & 3.3761 & 1.01259 \\
\hline S8 & 234 & 3.4744 & .91798 \\
\hline S9 & 234 & 3.6538 & .84142 \\
\hline S12 & 234 & 3.6538 & .79419 \\
\hline S11 & 234 & 3.7308 & .88390 \\
\hline S1 & 234 & 3.7521 & .93484 \\
\hline S5 & 234 & 3.7650 & .76980 \\
\hline S2 & 234 & 3.7692 & .84289 \\
\hline S14 & 234 & 3.8077 & .78709 \\
\hline S3 & 234 & 3.8162 & .84177 \\
\hline S7 & 234 & 3.8376 & .68656 \\
\hline S10 & 234 & 3.8419 & .74451 \\
\hline S6 & 234 & 3.8590 & .70664 \\
\hline S4 & 234 & 3.8675 & .79939 \\
\hline
\end{tabular}

At the lowest mean value of 3.3761, the respondents hardly believed that the RMN fleet encouraged informal meetings but on the other hand, the respondents concurred that the fleet encouraged social activities outside the workplace (3.8077). On top of that, at a mean value of 3.4744 , the respondents hardly believed that the RMN fleet follows a systematic plan to rotate personnel in all departments. Nevertheless, they believed that the fleet encouraged detailed faceto-face (F2F) discussions of work issues.

On the other hand, the respondents agreed that involving the RMN fleet in joint operations/exercises supports knowledge through face-to-face interaction with others, and they also agreed that the RMN fleet conducted meetings, seminars and workshops to discuss the updating of work issues and agreed that the fleet invited its qualified members and external experts to speak about their beliefs, values and culture. These findings showed that the socialization (tacit to tacit) knowledge creation process took place within the organization. However, the respondents claimed that the fleet did not encouraged enough informal meetings for them to create knowledge and does not really follow systematic ways to rotate personnel for acquiring more knowledge. However, the descriptive statistics mean value data, ranging from 3.3761 to 3.8675 , indicated that the socialization mode took place and the researcher concluded that there are still rooms for improvement in the RMN fleet for knowledge creation processes in this mode.

\section{Externalization}

For externalization mode, the descriptive statistics distribution (see Table 6) shows that the respondents agreed that when others could not understand them, they were usually able to give examples to help in explaining any issues. At only the mean value of 3.5684 , the respondents hardly agreed that most of the time, they could transcribe some of the unorganized thoughts into concrete ideas. However, they tended to describe professional or technical terms with conversational language to help communication (3.8034).

Table 6: Descriptive Statistics of Externalization Items (see Appendix 1)

\begin{tabular}{|l|l|l|l|}
\hline Item Code & $\mathbf{N}$ & Mean & Std. Deviation \\
\hline E11 & 234 & 3.5641 & .82227 \\
\hline E2 & 234 & 3.5684 & .71587 \\
\hline E9 & 234 & 3.6239 & .81009 \\
\hline E4 & 234 & 3.6410 & .76356 \\
\hline E8 & 234 & 3.6410 & .74651 \\
\hline E6 & 234 & 3.6453 & .81182 \\
\hline E7 & 234 & 3.6795 & .73234 \\
\hline E13 & 234 & 3.6880 & .77023 \\
\hline E10 & 234 & 3.7051 & .79336 \\
\hline E1 & 234 & 3.7179 & .81663 \\
\hline E12 & 234 & 3.7735 & .68395 \\
\hline E5 & 234 & 3.7821 & .69912 \\
\hline E3 & 234 & 3.8034 & .69627 \\
\hline
\end{tabular}


The respondents tended to use analogy when expressing abstract or theoretical concepts. They also agreed that they would help others to clearly express what was in their minds by encouraging them to continue what they are saying (3.7821), and they believed that their team developed new ideas through constructive dialogue by using figures and diagrams. The respondents facilitated creative and constructive conversation among group members, and they agreed that the RMN fleet documented its personnel's points of view regarding relevant topics, asked its personnel to report results of discussions to concerned parties, documented the findings of conducted seminars, meetings, conferences, workshops and training programme, established the topics of the training programme and seminars conducted by its qualified members and external experts, and documented the useful experiences of its qualified members into reports, but hardly issued reports of externals based on its accumulated experience (3.5641).

These findings showed that the externalization knowledge creation process was taking place within the organization. The descriptive statistics mean value data (3.5641 to 3.8034) indicated that the externalization mode took place within the fleet, and the researcher concluded that there are also rooms for improvement in the fleet for knowledge creation processes in this mode.

\section{Combination}

For combination mode, the descriptive statistics (see Table ) for the mean values ranged between 3.5299 to 3.8675. This shows that the RMN fleet personnel practiced the combination mode of knowledge creation processes. The respondents agreed that during discussions, they tended to help organize ideas and made conclusions to facilitate the discussions (3.8205). When coming across problems, they tended to use their experiences to help solve problems (3.8675). The respondents also agreed that after every event, they had the habit of organizing and making summaries of what happened, and agreed that during discussions, they would organize everyone's thoughts in their minds. They also concurred that they like to collect new information and make connections between new and old knowledge to develop new concepts (3.8376). They claimed that they engaged in developing criteria to determine the value of new concepts, and their team conducted experiments and shared the newly developed concepts with the entire organization to evaluate the value of the concepts. They also believed that the RMN fleet classified information mentioned in networks, databases and reports, updated its databases, considered information mentioned in networks, databases and previous reports to develop its rules and decisions, used documented information as a means of connection between its personnel and with external bodies (e.g., stakeholders such as OEM, suppliers, sister services, private or other government agencies).

Table 7: Descriptive Statistics of Combination Items (see Appendix 1)

\begin{tabular}{|l|l|l|l|}
\hline Item Code & \multicolumn{1}{|c|}{$\mathbf{N}$} & \multicolumn{1}{|c|}{ Mean } & Std. Deviation \\
\hline C11 & 234 & 3.5299 & .78147 \\
\hline C13 & 234 & 3.5427 & .84425 \\
\hline C12 & 234 & 3.5641 & .80112 \\
\hline C4 & 234 & 3.5940 & .76521 \\
\hline C9 & 234 & 3.6197 & .92451 \\
\hline C3 & 234 & 3.6368 & .79192 \\
\hline C6 & 234 & 3.6709 & .72260 \\
\hline C10 & 234 & 3.6752 & .77879 \\
\hline C7 & 234 & 3.7009 & .66507 \\
\hline C8 & 234 & 3.7350 & .78498 \\
\hline C1 & 234 & 3.8205 & .64343 \\
\hline C5 & 234 & 3.8376 & .76352 \\
\hline C2 & 234 & 3.8675 & .72625 \\
\hline
\end{tabular}

They responded with the lowest mean values that the fleet hardly collected, classified and informed its personnel with reports and decisions issued by external bodies (3.5299), and the fleet was hardly dependent on relevant published research and reports to develop its policies and aims (3.5427). These findings showed that the combination knowledge creation process was taking place within the organization. However, based on the statistics, the researcher concluded that there are still rooms for improvement in combination mode and this could be improved by looking into utilizing documented information with external bodies and trying to depend on published research and reports to develop policies and aims.

\section{Internalization}

For internalization mode, the descriptive statistics (see 
Table ) show that the respondents agreed that after hearing new ideas or concepts, they tended to compare them with their experience to help them comprehend the meaning (3.7949). They agreed that they understood others' thoughts better by repeating what they said and asking them "is this what you mean?" Hence, they would tell others what they thought to ensure that their understanding was the same as theirs (3.7949). On the other hand, when they had finished saying something, they would ask the other person if it was necessary to repeat to make sure he/she understood exactly what they meant.

The respondents also agreed that their team-members used newly learned knowledge as the sources for the next time applications. Meanwhile, they concurred that when communicating with others, they would give others time to think about what they just discussed, and they claimed that they combined existing and new concepts in meaningful ways.

Table 8: Descriptive Statistics of Internalization Items (see Appendix 1)

\begin{tabular}{|l|c|c|c|}
\hline Item Code & $\mathbf{N}$ & Mean & Std. Deviation \\
\hline I11 & 234 & 3.6453 & .79039 \\
\hline I12 & 234 & 3.6624 & .81911 \\
\hline I2 & 234 & 3.6838 & .77126 \\
\hline I8 & 234 & 3.7094 & .93625 \\
\hline I10 & 234 & 3.7179 & .80605 \\
\hline I5 & 234 & 3.7265 & .82477 \\
\hline I13 & 234 & 3.7308 & .70570 \\
\hline I4 & 234 & 3.7393 & .79994 \\
\hline I9 & 234 & 3.7479 & .83928 \\
\hline I7 & 234 & 3.7564 & .74441 \\
\hline I6 & 234 & 3.7863 & .78973 \\
\hline I1 & 234 & 3.7949 & .71811 \\
\hline I3 & 234 & 3.7949 & .74740 \\
\hline
\end{tabular}

The respondents also agreed that the RMN fleet encouraged its personnel to join postgraduate courses (e.g., Diploma, Bachelor's degree, Master's degree or $\mathrm{PhD}$ ), facilitated the access to outcomes or recommendations of training programme, workshops and seminars and facilitated the access to its databases and the internet to get required information. In contrast, at the lowest mean value (3.6453), they claimed that the fleet hardly arranged meetings to explain the content of related reports or documents and hardly arranged meetings to explain and analyse the relevant reports issued by stakeholders such as OEM, suppliers, sister services, private or other government agencies (3.6624). Nevertheless, the respondents agreed the fleet believed that the available data and information strongly shaped its point of view and culture. These findings showed that internalization knowledge creation processes took place within the organization and was the highest mode practiced by the personnel of the RMN fleet based on the mean value data (3.6453 to 3.7949). However, comparatively the same with the three previously discussed modes of knowledge creation processes, there are still rooms for improvement in the RMN fleet for internalization mode, as well.

The difference between all four modes can be considered as minimal since the range of mean values are over 3 but less than 4 on the 5-points Likert scale. Nevertheless, as mentioned by the researchers previously, there are rooms for further improvement within the RMN fleet based on these survey findings. From the overall descriptive instrument item analyses, the assumption can be made that knowledge creation processes do exist within the RMN fleet. The knowledge creation extent and practices were recorded in socialization, externalization, combination and internalization modes, respectively.

\section{DISCUSSIONS}

It is observed that all the processes of the SECI model are confirmed as the modes for conversion of knowledge in the RMN fleet. However, the processes are not implemented within the fleet at the same degree. Below is the discussion of this study, which is divided according to all four knowledge creation processes in the SECI model.

\section{Socialization}

From the findings, it is observed that transferring of tacit knowledge from one person to another in the RMN fleet was achieved through discussions conducted in formal events such as, seminars, meetings and training programmes. However, Nonaka and Toyama [49] posited that the processes of this knowledge conversion usually take place during informal social meetings, where tacit knowledge is created and shared. Martín-de-Castro, López-Sáez, 
and Navas-López [66] concurred by stating that this process happens through shared experiences that take place in everyday social interactions. The environment and working conditions in the RMN fleet allow personnel to conduct daily face-to-face discussions with each other. The interaction between personnel within the fleet resulted in tacit knowledge being created through shared experience or passed through practice, guidance, observation, etc.

However, there was limited social context discussions with external parties such as other services or agencies. The fleet regards most informal discussions as being focused on social and personal interactions rather than being work related. Thus, higher management are reluctant and sometimes unwilling to give consent for informal socialization. Hofstede and Hofstede [67] posited that this higher management acts as a representation of high power distance. This is a norm in military organizations such as the RMN fleet, where higher level management have strong authority over their subordinates. This suggests that the fleet supports formal over informal discussions.

Nevertheless, the fleet has implemented internal and external training programmes, seminars and workshops to further enhance sharing of knowledge among its personnel. Through these programmes or events, personnel could add more knowledge and experience by the virtue of face-to-face discussions with others from the same organizations or from relevant external agencies, with every level of management and with subject matter experts. However, the personnel claimed that they had limited informal discussions due to higher management's perceived thoughts and limited external events to attend since only limited numbers had been invited.

\section{Externalization}

In the RMN fleet, transformation of tacit knowledge into explicit knowledge is mainly done by documenting the outcomes of seminars, meetings and training programmes. Documenting and reporting the outcomes of discussions from these events are tasks given to the personnel. Normally, the most senior one from a group will be responsible for doing so. As Easa [59] posited, documenting and reporting the outcomes of these events are effective methods for articulating personnel's tacit knowledge and converting the tacit into explicit knowledge. However, the findings suggested that there are differences in the willingness of the personnel in transferring their tacit into explicit knowledge. This needs the support of every management level to encourage and motivate all the personnel to volunteer in this process. Personnel were asked to give event feedback only to their superiors, and as a result, the access to the outcomes of events was limited. Accessibility to the reports is also limited since most of the formal reports are entered into the manual filing system and not entered into any database.

Hence, only personnel selected to attend these events got the benefits. This reveals that the RMN fleet needs to look into documenting feedback as an important aspect of its management since it is possibly a big aspect of fleet's lamentable behaviour. Documenting important issues is a must and making them available to all, with convenient and friendly access, will create awareness of the problems that might happen again in the future. The RMN fleet needs a systematic way of documenting all the data and information garnered for easy access by all personnel because when tacit knowledge is converted to become explicit knowledge, this knowledge should be shared among personnel to become the foundation of new knowledge [68].

To sum up, the limited extent of externalization processes in the RMN fleet was observed. These processes are observed in seminars, workshops, training and in discussions with personnel. However, the benefits of discussions are limited to those who attend these events, generally, and specifically to the personnel involved directly in the discussions. The fleet will miss opportunities for circulating and cascading the knowledge to all personnel if they ignore the process of documenting these discussions. This would reduce the benefits of the externalization knowledge creation process and result in some knowledge still remaining tacit and intangible.

\section{Combination}

Reformulating explicit knowledge, into clearer and more beneficial knowledge for the fleet and its personnel is the main purpose of the combination process. According to Easa [59], systematic knowledge is created from the conversion of existing explicit knowledge. The RMN fleet performs certain activities to implement this process, for example, by testing all the policies and procedures during table-top evolution, war gaming, and exercises as well as in 
operations. These measures were taken to test and improvise the available documentation because the nature of the aforementioned events and environment are dynamic. The fleet needs to keep pace with fast and vast changes in surroundings and technology. Continuously updating its databases, networks and reports, is a must. By utilizing updated instructions and reports on all relevant issues, the fleet may then take necessary actions or means to circulate and cascade them to all the fleet personnel.

Instructions, rules and directives from the HQ need to be clearly reformulated by the top management so that they become understandable and beneficial for the fleet. Personnel might interpret them wrongly without the guidance of the higher management level. This might create conflicts among the personnel and also conflicts between the personnel and higher management level. As a result, the personnel become conservative in dealing with reports from the higher management level.

These findings show the importance of the combination mode in the RMN fleet. The existing documented explicit knowledge in its inventory are important, and the processes of updating and reformulating them in accordance with the dynamic scenario, vast surroundings and fast changing technology need to be looked into for newly modified explicit knowledge. This existing knowledge needs to go through the reconfiguration process as recommended by Nonaka [10], i.e., by sorting out the knowledge and some additional processes needed to re-categorize and also re-contextualize, which will lead to new knowledge being promulgated.

\section{Internalization}

The RMN fleet encourages personnel to internalize explicit knowledge by accessing the outcomes of any training programme, studying relevant and related courses to the fleet, accessing the outcomes of seminars attended and accessing the fleet's databases. Easa [59] posited that in order to enrich personnel's tacit knowledge base, personnel can do so by internalizing explicit knowledge, i.e., by reading and digesting the documentation about their organization and jobs.

On the job training is important because internalizing knowledge is always associated with learning by doing Nonaka and Takeuchi [21], and this is widely practiced by the RMN fleet. Accessing relevant materials from events like seminars, workshops, training programmes, professional courses and databases is an important part of job training as the work in the fleet comprises mainly operational types of work. On the other hand, the fleet also supports personnel to attend practical training programmes organized by the fleet itself or organized by the HQ.

Internalization mechanisms such as accessing outcomes of training programmes, workshops or seminars and explaining content of documentation or reports are supported by the RMN fleet. Apart from that, the fleet also supports practical courses for the personnel to attend and acquiring relevant support materials for these events. Even though this support is not of the academic type, personnel still benefit by gaining knowledge when attending them.

However, apart from the support from the fleet managerial perspective, accessibility to documentation and databases is limited and unfriendly. Hence, the RMN fleet need to look into having more systematic and proper databases to further improve the internalization process.

\section{CONCLUSIONS}

It is concluded that all four modes of knowledge creation processes in the SECI model [21] are contributing to knowledge creation enhancement within the RMN fleet. As for the mechanisms used for knowledge creation enhancement, respondents and interviewees agreed that existing mechanisms such as social multimedia and ICT infrastructure on board can be utilized for deriving and cascading knowledge to become collective knowledge among the crew of a ship. Even personal gadgets can be used for knowledge creation enhancement since the trend of utilizing social multimedia, for example, WhatsApp, Facebook and Instagram, are widely used in the fleet. However, when it comes to personal belongings, there is a point to ponder, especially with regard to information security when using one's own personal gadgets to share data and information. On top of that, understanding, awareness, attitude and higher management's involvement are a few more points to ponder in realizing the objectives of the study.

Descriptive analysis showed that knowledge creation processes took place in the RMN fleet. The extent of the knowledge creation processes was identified, 
where all four modes of knowledge creation were practiced within the fleet. However, the extent varied from one mode to the other. According to the findings, externalization and internalization are the most common practices within the RMN fleet as compared to socialization and combination. Although the statistical data's mean value differences are quite close and similar in each mode, between 3 and 4 on the fivepoint Likert scale, there are still rooms for improvement for all SECI processes in the fleet. Hence, stimulating knowledge creation enhancement in the fleet needs to be focused more on the socialization and combination modes. Extracting all the personnel's tacit knowledge, testing and modifying existing explicit knowledge when it is necessary, needs to be adhered to quickly and to become a dynamic and on-going process. Although it is and will be a tedious process, it is paramount and a must for the RMN fleet to further improve in order to be an effective and efficient naval force to be reckoned with.

\section{Limitations}

It would be difficult if a study were to embark on investigating the SECI model with another navy fleet due to the nature of the military and security issues. On top of that, time and cost constraints will come into the picture, as well. It was also difficult for the researcher to conduct the study with regard to the implication of gender differences with the SECI model because there were not many female personnel serving on board the RMN ships (observations were made through survey with only 11 female personnel).

\section{Future Research}

Future research is recommended on the fast and vast development of technologies within the military context. More detailed research on the SECI model and technology would be beneficial in identifying proper and systematic mechanisms for knowledge management and knowledge creation processes within the organization.

The use of other research methodology might also be useful to contribute to the body of knowledge and organizations. This could provide a broader scope on SECI model knowledge creation processes. Finally, a study on different styles of leadership or tasks could provide more interesting findings on how each of these knowledge creation processes or the processes as a whole could be different.

\section{REFERENCES:}

[1] Memon, S. B. (2015). Relationship between organizational culture and knowledge creation process in knowledge-intensive banks. Queen Margaret University.

[2] Salleh, K. M., \& Sulaiman, N. L. (2016). Malaysian HRD practitioners' competencies in manufacturing and non-manufacturing sector: An application of the competency model. Man in India, Serials Publications, 4(1169)

[3] Shih, K.H., Chang, C.J., \& Lin, B. (2010). Assessing knowledge creation and intellectual capital in banking industry. Journal of Intellectual Capital, 11(1), 74-89.

[4] Sikombe, S. \& Phiri, M. A. (2019). Exploring tacit knowledge transfer and innovation capabilities within the buyer-supplier collaboration: A literature review. Cogent Business \& Management, 6: 1683130.

[5] Cavusgil, T., Calantone., S., \& Zhao, Y. (2003). Tacit knowledge transfer and firm innovation capability. Journal of Business \& Industrial Marketing, 18(1), 6-21.

[6] Gonzalez, R., \& Melo, T. (2018). Innovation by knowledge exploration and exploitation: An empirical study of the automotive Industry. Gest. Prod., São Carlos, 25(1), 1-1510.1590/0104530 X3899-17.

[7] Amber, Q., Ahmad, M., Khan, I. A., \& Hashmi, F., A. (2019). Knowledge sharing and social dilemma in bureaucratic organizations: Evidence from public sector in Pakistan, Cogent Business \& Management (2019), 6: 1685445.

[8] Choi, Y. (2016). The impact of social capital on employees' knowledge-sharing behavior: An empirical analysis of US federal agencies. Public Performance \& Management Review, 39(2), 381-405.

[9] Kianto, A., Vanhala, M., \& Heilman, A. (2016). The impact of knowledge management on job satisfaction. Journal of Knowledge Management, 20(4), 621-636.

[10] Nonaka, I. (1994). A dynamic theory of organization knowledge creation. Organization Science 5(1), 1-118.

[11] Salisbury, M. (2008). A framework for collaborative knowledge creation. Knowledge Management Research \& Practice, 6(3), 214224. 
Shaftdean \& Ismawati/ International Journal of Business and Management, 4(3) 2020, Pages: 22-39

[12] Kaba, A., \& Ramaiah, C. K. (2017). Demographic differences in using knowledge creation tools among faculty members. Journal of Knowledge Management, 21(4), 857-871.

[13] Mehralian, G., Nazari, J. A. \& Ghasemzadeh, P. (2018). The effects of knowledge creation process on organizational performance using the BSC approach: The mediating role of intellectual capital. Journal of Knowledge Management, 22(4), 802-823.

[14] Manuri, I. (2012). Knowledge management in the Malaysian Armed Forces: A study on perceptions and applications in the context of an information and communication technology environment. The Doctoral Research Abstracts. IPSis Biannual Publication, 2(2). Institute of Graduate Studies, UiTM, Shah Alam.

[15] Nielsen, \& Razmerita (2014). Motivation and knowledge sharing through social media within Danish organizations. IFIP Advances in Information and Communication Technology, 429, 197-213.

[16] MTL(N1-2).500-2/15/29 - (5) dated 14 Nov 2017. Chief of Navy feedback on Board of Inquiry (BOI) report.

[17] MTL/NTAD(SEK-UND)/4418/5 - (12) dated 12 Sep 2014. Chief of Navy feedback on Board of Inquiry (BOI) report.

[18] Liu, H., Fu, Y., Wang, X., \& Fang, Y. (2014). Empirical analysis of the relationship between HR professionals' competency and enterprise performance. International Conference on Management Science and Management Innovation (MSMI 2014), 546-553, Atlantic Press.

[19] Stovel, M., \& Bontis, N. (2002). Voluntary turnover: Knowledge management - friend or foe? Journal of Intellectual Capital, 3(3), 303322.

[20] Arner, D. W., \& Schou-Zibell, L. (2011). Asian regulatory responses to the global financial crisis. Global Journal of Emerging Market Economies, 3(1).

[21] Nonaka, I., \& Takeuchi, H. (1995). The knowledge-creating company. How Japanese companies create dynamics of innovation. Oxford, England: Oxford University Press.

[22] Von Krogh, G., Nonaka, I., \& Rechsteiner, L. (2012). Leadership in organizational knowledge creation: A review and framework. The Journal of Management Studies, 49(1), 240-277.
[23] Earl, M. (2001). Knowledge management strategies: Toward a taxonomy. Journal of Management Information System, 18(1), 215233.

[24] Bartczak, S. (2002). Identifying barriers to knowledge management in the United States military. AMCIS 2002 Proceedings 343, 24762480.

[25] Ali, H. M. \& Ahmad, N.H. (2006). Knowledge management in Malaysian banks: A new paradigm. Journal of Knowledge Management Practice, 7(3).

[26] Blesio B., Molignani R. (2000). Implementation strategies for knowledge management in banking, Part 1 (September). Analysis of Demand: IDC.

[27] Hur, D., \& Kim, H. (2014). Supplier development as knowledge transfer routines: Managerial versus operational knowledge. Academy of Management Annual Meeting Proceedings, 2014(1), 12387.

[28] Dalkir, K. (2011). Knowledge management in theory and practice. Massachusetts Institute of Technology.

[29] Gunnlaugsdottir, J. (2003). Seek and you will find, share and you will benefit: Organizing knowledge using groupware systems. International Journal of Information Management, 23(5), 363-380.

[30] Mahdi, O. R., Nassar, I. A., \& Almsafir, M. K. (2018). Knowledge management processes and sustainable competitive advantage: An empirical examination in private universities. Journal of Business Research, 94(Jan 2019), 320-334.

[31] Davenport, T. H., \& Marchand, D. (1999). Is KM just good information management? In D. Marchand, T. H. Davenport, \& T. Davenport (Eds.), Mastering information management (pp. 2-3). Harlow: FT Prentice-Hall.

[32] Nonaka, I., \& Takeuchi, H. (1995b). The knowledge-creating company. How Japanese companies foster creativity and innovation for competitive advantage. New York, NY: Oxford University Press.

[33] Newell, S., Robertson, M., Scarbrough, H., \& Swan, J. (2009). Managing knowledge work and innovation. Hampshire, England: Palgrave Macmillan.

[34] Davenport, T. H. (2013). Big data in big companies. International Institute for Analytic. 
Shaftdean \& Ismawati/ International Journal of Business and Management, 4(3) 2020, Pages: 22-39

[35] Polanyi, M. (1966). The Tacit Dimension. London, England: Routledge.

[36] Chugh, R. (2017). Barriers and enablers of tacit knowledge transfer in Australian Higher Education Institutions. International Journal of Education and Learning Systems http://iaras.org/iaras /journal/ijels

[37] Gourlay, S. (2006). Conceptualizing knowledge creation: A critique of Nonaka's theory. Journal of Management Studies, 43(7), 1415-1436.

[38] Jasimuddin, S. M., Klein, J .H., \& Connell, C. (2005). The paradox of using tacit and explicit knowledge: Strategies to face dilemmas. Management Decision, 43(1), 102-112.

[39] Polanyi, M. (1967). Sense-giving and sense reading. The Royal Institute of Philosophy, 42(162), 301-325.

[40] Wilson, T. D. (2002). The nonsense of knowledge management. Information Research, $8(1)$.

[41] Collins, H. (2010). Tacit and explicit knowledge. Chicago, IL: The University of Chicago Press.

[42] Rutten, W., Blaas-Franken, J., \& Martin, H. (2016). The impact of (low) trust on knowledge sharing. Journal of Knowledge Management, 20(2), 199-214.

[43] Suppiah, V., \& Sandhu, M. S. (2011). Organisational culture's influence on tacit knowledge-sharing behaviour. Journal of Knowledge Management, 15(3), 462-477.

[44] Nonaka, I., \& Takeuchi, H. (1996). A theory of organizational knowledge creation. International Journal of Technology Management, 11(7-8).

[45] Park, C., Vertinsky, I., \& Becerra, M. (2014). Transfer of tacit vs explicit knowledge and performance in international joint ventures: The role of age. International Business Review, 24(2015), 89-101.

[46] Grimsdottir, E., Edvardsson, I.R. \& Durst, S. (2019). Knowledge creation in knowledgeintensive small and medium sized enterprises. International Journal Knowledge-Based Development, 10(1), 75-94.

[47] Garvin, D.A. (1993). Building a learning organization. Harvard Business Review, 71(4), 78-91.

[48] Jogulu, U. D., \& Pansiri, J. (2011). Mixed methods: A research design for management doctoral dissertations. Management Research Review, 34(6), 687-701.
[49] Nonaka, I., Toyama, R., \& Konno, N. (2000). SECI, Ba and leadership: A unified model of dynamic knowledge creation. Long Range Planning, 33, 5-34.

[50] Hargreaves, D. H. (1999). The KnowledgeCreating School. British Journal of Educational Studies, 47(2), 122-144.

[51] Schaap, H., de Bruijn, E., Van der Schaaf, M. F., \& Kirschner, P. A. (2009). Students' personal professional theories in competence-based vocational education: the construction of personal knowledge through internalisation and socialisation. Journal of Vocational Education \& Training, 61(4), 481-494.

[52] Baldé, M., Ferreira, A.I. \& Maynard, T. (2018). SECI driven creativity: The role of team trust and intrinsic motivation. Journal of Knowledge Management, 22(8), 1688-1711.

[53] Yeh, Y., Huang, L., \& Yeh, Y. (2011). Knowledge management in blended learning: Effects on professional development in creativity instruction. Computers \& Education, 56(1), 146-156.

[54] Hubers, M. D., Poortman, C. L., Schildkamp, K., Pieters, J. M., \& Handelzalts, A. (2016). Opening the black box: knowledge creation in data teams. Journal of Professional Capital and Community, 1(1), 41-68.

[55] Allal-chérif, O., \& Makhlouf, M. (2016). Using serious games to manage knowledge: The SECI model perspective. Journal of Business Research, 69(5), 1539-1543.

[56] Bandera, C., Keshtkar, F., Bartolacci, M. R., Neerudu, S., \& Passerini, K. (2017). Knowledge management and the entrepreneur: Insights from Ikujiro Nonaka's Dynamic Knowledge Creation model (SECI). International Journal of Innovation Studies, 1(3), 163-174.

[57] Huang, Y., Basu, C. \& Hsu, M.K. (2010). Exploring motivation of travel knowledge sharing on social network sites: An empirical investigation of U.S. college students. Journal of Hospitality Marketing and Management, 19(7), 717-734.

[58] Muina, G. F. E., Martin, G., \& Lopez Saez, P. (2002). The knowledge-creation process: A critical examination of the SECI model. Third European Conference on Organizational Knowledge, Learning and Capabilities, Athens, 5-6. 
Shaftdean \& Ismawati/ International Journal of Business and Management, 4(3) 2020, Pages: 22-39

[59] Easa, N. F. H. (2012). Knowledge management and the SECI model: A study of innovation in the Egyptian banking sector. Stirling Management School, University of Stirling.

[60] McClure M, \& Faraj S. (2000). "It is what one does:" Why people participate and help others in electronic communities of practice. The Journal of Strategic Information Systems, 9, 155-173.

[61] Sekaran, U., \& Bougie, R. (2016). Research methods for business: A skill building approach. New York, NY: John Wiley \& Sons Inc.

[62] Sekaran, U. (2013). Research methods for business: A skill building approach. New York, NY: John Wiley \& Sons Inc.

[63] Kumar R. (2011). Research methodology: A step-by-step guide for beginners. Sage Publication Inc.

[64] Nunnally, J. C. (1978). Psychometric theory. New York: McGrawHill.

[65] Treiman, D. J. (2009). Quantitative data analysis: Doing social research to test ideas. Jossey-Bass. San Francisco, CA.

[66] Martín-de-Castro, G., López-Sáez, P., \& NavasLópez, J. E. (2008). Processes of knowledge creation in knowledge-intensive firms: Empirical evidence from Boston's Route 128 and Spain. Technovation, 28(4), 222-230.

[67] Hofstede, G. and Hofstede, G.J. (2005), Cultures and Organizations: Software of the Mind. McGraw-Hill, New York, NY.

[68] Nonaka, I., \& Toyama, R. (2003). The knowledge-creation theory revisited: Knowledge creation as a synthesizing process. Knowledge Management Research \& Practice, $1,2-10$. 
Appendix 1 - Instrument items adapted from [59]

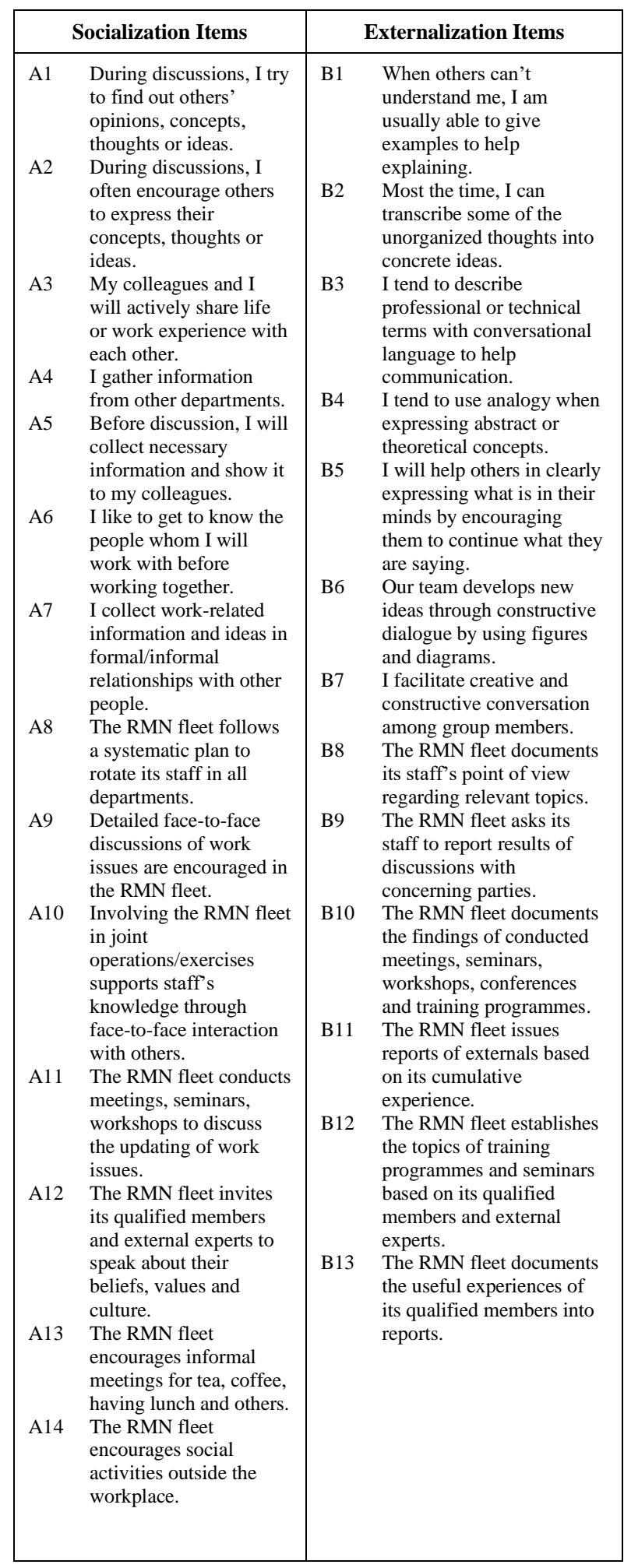

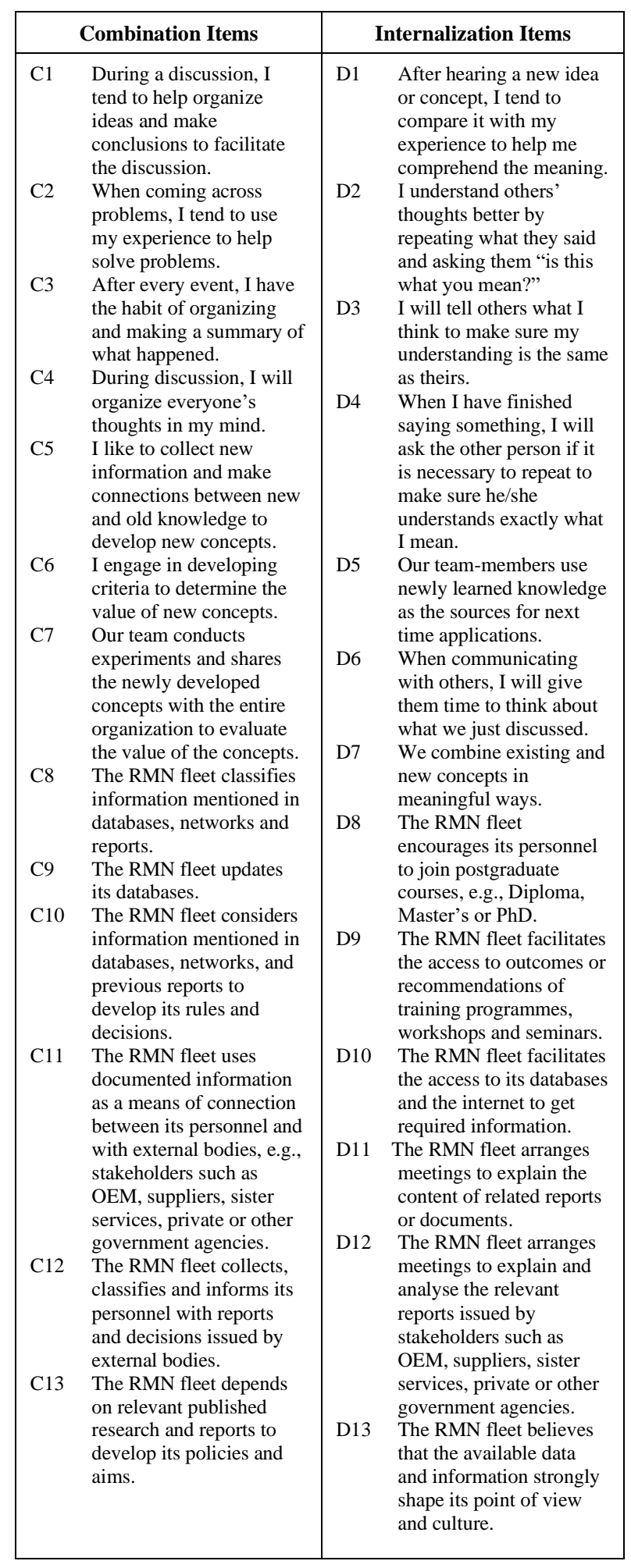

